\title{
La custodia del territorio como herramienta para la recuperación del patrimonio cultural: el caso de Mas Blanco
}

\author{
Sara Gil Rubio, David Salesa Duro | Asociación Recartografías \\ URL de la contribución <www.iaph.es/revistaph/index.php/revistaph/article/view/4476>
}

La vinculación y dependencia del ser humano con su entorno sigue siendo absoluta hoy en día. Las comunidades humanas llevan influyendo de manera significativa sobre el entorno desde hace miles de años mediante el empleo del fuego, la caza, los cambios de usos del suelo para agricultura y, más recientemente, mediante la deforestación, la ganadería, la sobreexplotación de recursos y los crecimientos exponenciales de la población (STEFFEN; GRINEVALD; CRUTZEN et ál., 2011). Esta profunda conexión del ser humano se ha visto camuflada por el fenómeno de la globalización y la concentración de las personas en "burbujas" urbanas.

El proceso de la despoblación, conducido por una interacción compleja entre factores sociales, culturales, económicos y ecológicos, especialmente agravado en la Península Ibérica, está llevando a la pérdida inexorable de patrimonio histórico-cultural, el cual supone un fiel reflejo de los pasos seguidos por las sociedades hasta el día de hoy. Nos encontramos en la obligación moral de recuperar, mantener y conservar todo aquello que sea capaz de enseñarnos de dónde venimos y la importancia que tenían las comunidades rurales en el mantenimiento de un equilibrio dinámico con su entorno, equilibrio que si se pierde puede generar consecuencias catastróficas sobre el medio en el que habitan estas comunidades (ALLOZA, 2011).

En el marco de recuperación del patrimonio cultural, así como del modo de vida de las comunidades tradicionales, podemos encontrar el proyecto de la Asociación Recartografías. El proyecto se desenvuelve en Mas Blanco, uno de los 15 barrios pertenecientes al municipio de San Agustín (Teruel). Este mas está dentro de la denominada serranía celtibérica o Laponia del Sur, territorio que abarca unos $65.000 \mathrm{~km}^{2} \mathrm{e}$ incluye municipios de diez provincias (Soria, Teruel, Guadalajara, Cuenca, Valencia, Castellón, Zaragoza, Burgos, Segovia y La Rioja) y cuya densidad de población es de aproximadamente 7,34 hab/km² (CERDÀ, 2017).

El origen de Mas Blanco puede situarse en la llegada de varias familias de la Sierra de Gúdar en la primera mitad del s. XIX (ROMERO RENAU, 2018). A mediados del s. XX, poco antes de comenzar el éxodo rural, en Mas Blanco llegaron a habitar casi un centenar de personas constituyéndose como uno de los barrios más importantes de la zona. Su actividad principal era el cultivo de vid y el cereal, así como la presencia la ganadería ovina.

Como ejemplo de comunidad desde el sentido antropológico, en Mas Blanco se creó en 1919 la "Sociedad La Humanitaria" que tenía el objetivo de garantizar la ayuda y socorro mutuo en caso de enfermedad y defunción. Sus miembros constituían anualmente un fondo común para poder pagar la asistencia médica y se organizaban para poder atender a los enfermos.

También se reflejó la organización social en el patrimonio cultural del barrio. En Mas Blanco encontramos diferentes construcciones comunales: el horno, el aljibe, la prensa, la escuela y la casa de la maestra. Estos edificios fueron construidos por y para los masoveros con los pocos recursos que disponían. Se organizaban y colaboraban para construirlos y posteriormente para utilizarlos entre todos haciendo turnos para amasar en el horno, empleando el agua del aljibe para el ganado o empleando la prensa para fabricar vino. Sin embargo, a partir de los años 60 experimentaría, como muchos municipios, un intenso éxodo rural. La falta de infraestructuras básicas que permitieran dotar al mas de electricidad, agua corriente, línea telefónica o caminos por 
los que transitar con facilidad, así como la percepción de que las ciudades ofrecían más oportunidades fueron algunos factores que propiciaron el éxodo. A estas dificultades se le suma la dureza y la amplitud temporal de la posguerra en esta zona, factores sinérgicos que llevaron a este barrio a una demotanasia profunda (CERDÀ, 2017). La pérdida de población supuso la desaparición del entramado social que hacía posible la gestión comunitaria y el mantenimiento del patrimonio de Mas Blanco.

En el año 2014, Recartografías inicia su proyecto de recuperación y rehabilitación del patrimonio rural a través de la custodia del territorio. El acuerdo de custodia, firmado con la administración local, establece que ésta cede el uso de los edificios comunales del barrio: escuela, horno y casa de la maestra. Este pacto voluntario y sin aprovechamiento económico tiene el objetivo de reactivar el entramado social y organización comunitaria del barrio a través de la rehabilitación de dichos edificios y el fomento del patrimonio cultural asociado. También se han llegado a acuerdos similares con algunos antiguos propietarios del mas como ayuda a la actividad de la asociación. Pese al importante deterioro de los edificios, se ha conseguido su recuperación utilizando principalmente técnicas de construcción tradicionales y de bajo impacto. Hoy en día todos ellos están totalmente restaurados y forman parte del Museo de las Masías y de la Memoria Rural, proyecto principal de la asociación inaugurado el pasado mes de enero.

El museo de Mas Blanco es un museo al aire libre que muestra cómo era la vida de los masoveros o habitantes de las masías, el hábitat disperso de montaña característico de Teruel, así como de muchos otros territorios de Aragón, Valencia y Catalunya. También se exponen episodios históricos clave que, junto a ciertas políticas, favorecieron el éxodo de un gran número de familias. El museo se ha planteado como un espacio vivo, donde desarrollar diversas actividades culturales, sociales y ambientales. Otro de los interesantes resultados de este proyecto ha sido la toma de conciencia por parte de los antiguos habitantes del mas sobre la importancia y el valor que tenía su forma de vida.

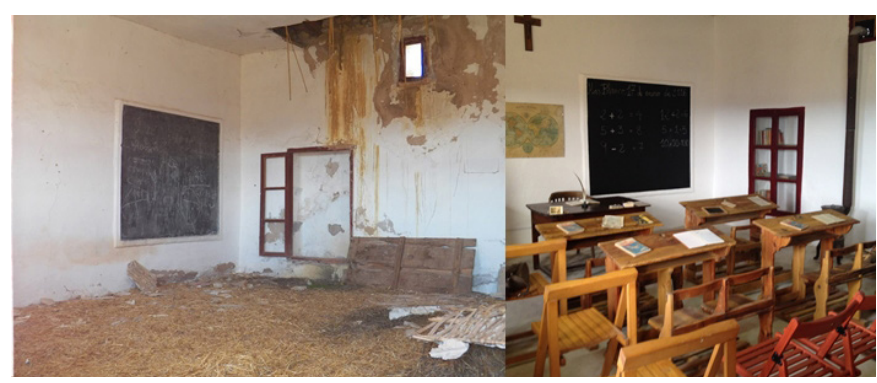

Antigua escuela, uno de los espacios que componen el Museo de las Masías y de la Memoria Rural. Estado inicial en 2014; a la derecha, estado actual | fuente Asociación Recartografías

En definitiva, la despoblación es un proceso perjudicial que manifiesta sus efectos en todas las vertientes vinculadas al territorio: economía, medio ambiente, patrimonio cultural y desaparición de la comunidad rural. Debe buscarse una proporción óptima entre la preservación del patrimonio y la resignificación: otorgar un valor añadido a este tipo de comunidades y espacios pero sin perder el sentido de sus orígenes y causas. En consonancia con esto, Recartografías, mediante la custodia del territorio, pretende aportar una pequeña ayuda para evitar esta despoblación y dignificar el modo de vida rural tradicional, contribuyendo a su vez la preservación y fomento del patrimonio cultural de estas comunidades.

\section{BIBLIOGRAFÍA}

- ALLOZA, J.A. (2011) Grandes incendios forestales en Teruel. ¿Del desierto demográfico al desierto ambiental? Nuestros montes no se olvidan [en línea], 22 de julio de $2011<$ https:// nuestrosmontesnoseolvidan.wordpress.com/2011/07/22/ grandes-incendios-forestales-en-teruel-\%C2\%BFdel-desiertodemografico-al-desierto-ambiental/> [Consulta: 14/06/2019]

- CERDÀ, P. (2017) Los últimos, voces de la Laponia española. Logroño: Pepitas de calabaza, 2017

- ROMERO RENAU, L. DEL (2018) Despoblación y abandono de la España rural. El imposible vencido. Valencia: Tirant editorial, 2018

- STEFFEN, W.; GRINEVALD, J.; CRUTZEN, P.; MCNEILLI, J. (2011) The Anthropocene: conceptual and historical perspectives. Philosophical Transactions of the Royal Society A: Mathematical, Physical and Engineering Sciences, 369, 2011, pp. 842-867 <https://doi.org/10.1098/rsta.2010.0327> [Consulta: 27/08/2019] 